\title{
New Low Band Gap Conjugated Conducting Poly(2-nonylthieno[3,4-d]thiazole): Synthesis, Characterization, and Properties
}

\author{
In Tae Kim." Joo Hyoung Lee, and Sang Woo Lee \\ Deparment of Chemistry, Kwangwoon University, Seoul 139-701, Korea. "E-mail: itkim@kw.ac.kr \\ Received Angust 11, 2007
}

Key Words : Conducting polymers, Low band gap, Electrochemically, Thiophene

Highly conjugated conducting polymers are known to be excellent materials for electronic devices like electrolytic capacitors, actuators, sensors, artificial muscles, and lightemitting diodes (LEDs). ${ }^{1}$ In particular, low band gap conducting polymers draw much attention because they potentially provide materials with high conductivities as well as desirable optical properties. The first low band gap conducting polymer, poly (isothianaphthene), which was reported by Wuld et al and its band gap was about $1 \mathrm{eV}^{2}$ This is caused by the intrinsic structure of the polymer backbone which trends to stabilize the electronic quinoid state. Several low band gap conducting polymers derived from thieno $[3,4-b]$ pyrazine, ${ }^{3}$ isothianaphthene ${ }^{2}$ and thieno$[3,4-b]$ thiophene $e^{4 a, 4 b}$ have been reported. From Bredas and his co-workers, the band gap is more or less proportional to the bond length alternation along the polymer backbone. In particular, polythiophene with increased quinoid form reduces the band gap. ${ }^{4 h}$. Recently, we have reported a series of solution processible low band gap conducting polymers such as poly(I-dodecyl-2,5-pyrrolylenevinylene) $(\mathrm{Eg}=1.67$ $\mathrm{eV})^{6}$ and poly $(3,4-\mathrm{ethylenedioxypyrole})(\mathrm{Eg}=1.57 \mathrm{eV}){ }^{7}$

Herein, we now communicate the new successful synthesis, characterization, and properties of poly (2-nonylthieno [3,4$d$ thiazole) (1) as a new solution processible low band gap<smiles>[R]c1nc(C(=O)OCC)c(C(=O)OCC)s1</smiles><smiles>[R]c1nc2c(s1)CSC2</smiles><smiles>[R]c1nc2c(C(C)(C)C)sc(C(C)(C)C)c2s1</smiles>

Scheme 1. i) LAH, diethyl ether, $0{ }^{\circ} \mathrm{C} \sim \mathrm{RT}, 6 \mathrm{~h}, 53 \%$ ii) Phosphorous tribronide, $0^{\circ} \mathrm{C} \sim \mathrm{RT}, 7 \mathrm{~h}, 98 \%$; iii) $\mathrm{Na}_{2} \mathrm{~S} \cdot 9 \mathrm{H}_{2} \mathrm{O}, 0^{\circ} \mathrm{C}$ $\sim$ RT, 2 h, 36\%; iv) DDQ, benzene, $5{ }^{\circ} \mathrm{C} \sim$ RT, $14 \mathrm{~h}, 96 \%$; v) electrochemical polymerization, $48 \%$. conducting polymer and a new preparative route to 2-alkylthieno[3,4- $d$ ] thiazole that can be applicab]e to synthesize the new conducting polymer as shown in Scheme 1 .

\section{Results and Discussion}

The monomer, 2-nonylthieno[3,4-d]thiazole 2, was prepared as shown in Scheme 1. 2-nonyl-4,5-bis(diethyldicarboxylate)thiazole 6 was synthesized according to a method reported in the literature. ${ }^{\text {8abc }}$ Reduction of 6 with lithium aluminum hydride $(\mathrm{LAH})$ at $0{ }^{\circ} \mathrm{C}$ gave $70 \%$ yields of compound 5 . The compound 5 reacted with $\mathrm{PBr}_{3}$ for 1 h at 0 ${ }^{\circ} \mathrm{C}$, and for $6 \mathrm{~h}$ at room temperature to yield compound 4 . Bromide 4 reacted with $\mathrm{Na}$ S to yield cyclic 4,6-dihydro-2nonylthieno $[3,4-d]$ thiazole 3 that was a valuable intermediate for synthesis of 2-alkylthieno[3,4-d]thiazole as monomer. Oxidation of cyclic product 3 with 2,3-dichloro5,6 -dicynide-1,4-benzoquinone (DDQ) for $18 \mathrm{~h}$ at $5^{\circ} \mathrm{C}$ gives 2 in $96 \%$ yield. The reaction pathway illustrated in Scheme 1 offers a new and convenient route to prepare 2-alkylthieno[3,4- $d]$ thiazoles starting from the parent thiophene and provides a potential monomer for the synthesis of conductive polymers.

Figure I shows cyclic voltammetric polymerization of monomer $2\left(0.05 \mathrm{M}\right.$, in $\left.\mathrm{CH}_{3} \mathrm{CN}\right)$ in $0.1 \mathrm{M} \mathrm{LiClO}_{4} /$ acetonitrile electrolyte solution at a scan rate of $60 \mathrm{mV} / \mathrm{s}$ using a

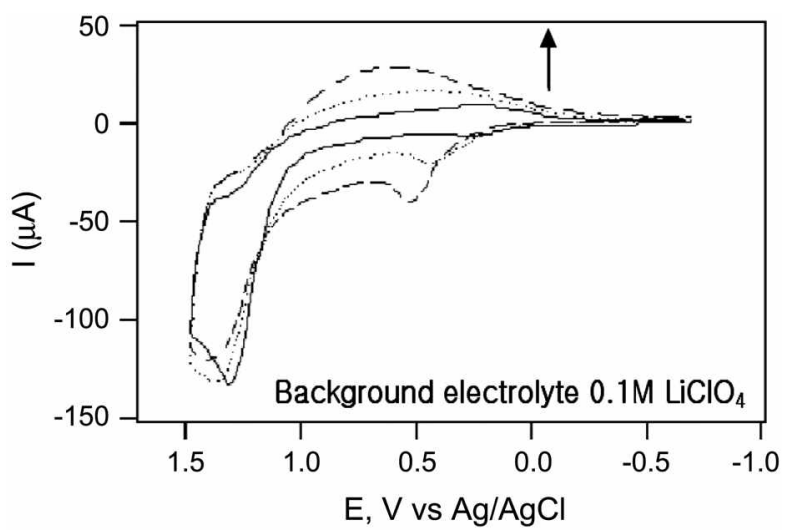

Figure 1. Cyclovoltammetric polymerization of monomer (2) $(0.05$ $\mathrm{M}$ ) in $0.1 \mathrm{M} \mathrm{LiClO} /$ acetonitrile electrolyte solution at a scan rate of $60 \mathrm{mV} / \mathrm{s}$ using a Pt working electrode and Pt count electrode. Potential reported vs $\Lambda \mathrm{g} / \mathrm{\Lambda CCl}$ reference elcetrode. (at $1^{\text {st }}$ scan $(\longrightarrow), 3^{\text {Id }} \operatorname{scan}(\cdots \cdots), 6^{\text {th }} \operatorname{scan}(-)$. 
$\mathrm{Pt}$ working electrode and $\mathrm{Pt}$ count electrode under inert atmosphere. Owing to the presence of unsubstituted $\alpha$ and $\alpha$-positions on the thiophene ring of the monomer 2 , the radical cation internediates resulting from electrochemical oxidation can subsequently couple to form polymer 1 . The broad cathodic and anodic processes at low potential, which increase in intensity with the number of scans, resulted from conducting polymer film growth.

The electrochemically deposited polymer 1 on a $\mathrm{Pt}$ electrode was dissolved in THF and reprecipitated with methanol. Then a 2 day Soxhlet extraction with methanol was conducted on the deep blue-black precipitate. The deep blue-black precipitate was dried under vacuum to yield 64 $\mathrm{mg}(24 \%)$ of the polymer 1 . The polymer 1 was soluble in a variety of organic solvents such as THF, $\mathrm{CHCl}_{3}, \mathrm{CH}_{2} \mathrm{Cl}_{2}$ and DMF. The elemental analysis as well as the spectral properties of polymer 1 agreed with the structure.

Comparison of the ${ }^{1} \mathrm{H}$ NMR spectral of monomer 2 and polymer 1 showed complete disappearance of the doublet at $\delta 7.16$ and 7.45 , attributable to protons on the thiophene ring in the monomer 2 , indicating a high molecular weight polymer with no visible end groups. In addition, comparison of the IR spectra of the monomer 2 and polymer 1 showed complete disappearance of the strong bands at $3065 \mathrm{~cm}^{-1}$ and $3054 \mathrm{~cm}^{-1}$, attributable to aromatic $\mathrm{C}-\mathrm{H}$ bond stretching vibration on the ring. These results suggest that the coupling reaction was involved at the $\alpha$ - and $\alpha^{\prime}$-positions of thiophene ring in the monomer 2 . Molecular weight approximation was carried out using GPC (polystyrene standards) with THF as mobile phase and a weight-average molecular weight $\left(\mathrm{M}_{\mathrm{w}}\right)$ was approximated to be $1.61 \times 10^{+}$for the polymer 1 . The number-average molecular weight $\left(\mathrm{M}_{\mathrm{n}}\right)$ of the polymer 1 was approximated to be $1.24 \times 10^{4}$. The average degree of polymerization (DP), for these approximate molecular weights, was 45 . It is clear from GPC data that polymer 1 has high molecular mass with narrow molecular weight distributions. The electrical conductivity of polymer 1 was measured using a standard four-probe technique. Polymer 1 gave an electrical conductivity of about $1.0 \times 10^{-4} \mathrm{Scm}^{-1}$ with $\mathrm{I}_{2}$ as dopant and $1.5 \times 10^{-2} \mathrm{Scm}^{-1}$ with $\mathrm{NaC}_{10} \mathrm{H}_{7}$. Thermogravjmetric analysis (TGA; $\mathrm{N}_{2} ; 10 / \mathrm{min}$ ) of the polymer 1 showed the onset of decomposition at $160{ }^{\circ} \mathrm{C}$ and $5 \%$ weight loss by $240^{\circ} \mathrm{C}$.

The redox properties of polymer 1 were subsequently characterized by cyclic voltammetry (CV). The $\mathrm{CV}$ curve of the electrochemically deposited polymer 1 on a Pt electrode in the potential range -2.0 to $2.0 \mathrm{~V}$ at $60 \mathrm{mV} / \mathrm{s}$ scan rate is shown in Figure 2. There is a couple of oxidation peak at 1.2 $\mathrm{V}$ related to $p$-doping of the polymer 1 and its reduction peak at $-1.3 \mathrm{~V}$ related to $n$-doping of the polymer 1 . Both $p$ and $n$-doping processes are reversible in the electrolyte solution employed. Therefore, electrochemically determined band gap, derived from the difference between onset potentials for oxidation and reduction of polymer 1 was at about $1.26 \mathrm{eV}$.

To compare the results from electrochemical characterization on band gap, polymer 1 was also characterized by

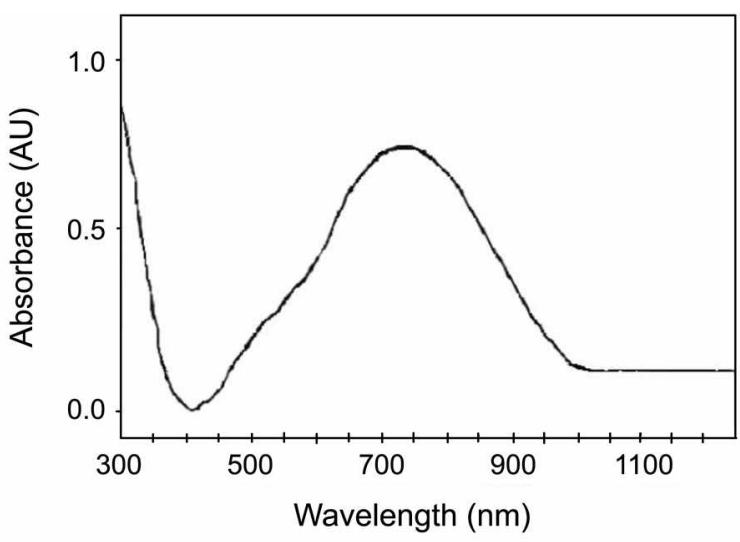

Figure 2. UV-vis spectrum of polymer 1 in $\mathrm{CHCl}_{3}$.

electronic absorption spectroscopy. The UV-vis spectrum of the polymer 1 showed $\lambda_{n n}$ (in $\mathrm{CHCl}_{3}$ solution) at $710 \mathrm{~nm}$ with the band edge at $953 \mathrm{~nm}(1.30 \mathrm{eV})$ as shown in Figure 2, somewhat higher than derived from the electrochemical method. The new polymer 1 with a thiazole group on thiophene ring has lower band gap by about $0.9 \mathrm{eV}$ than that of polythiophene. Hence, we assume that the lower band gap of polymer 1 comes from the thiazole as electron withdrawing group on thiophene ring.

We have shown that the monomer 2 undergoes facial electrochemical polymerization to yield a new conjugated polymer with a low band gap of $1.26 \mathrm{eV}$. The electrochemical oxidation/reduction reversibility of the polymer also indicates that the polymer has good charge transport properties. Its good solubility and processability into thin films renders polymer 1 suitable for electronic applications. We are presently exploiting the versatility of thieno[3,4$d$ thiazole chemistry through the preparation of numerous derivatives with optimized properties.

\section{Experimental Section}

2-Nonyl-4,5-bis(hydroxylmethyl)thiazole (5). To a solution of 2-nonyl-4,5-bis(diethyldicarboxylate)thiazole 6 $(16.5 \mathrm{~g}, 46.5 \mathrm{mmol})$ was in $500 \mathrm{~mL}$ of dried diethyl ether, lithium aluminum hydride $(3.52 \mathrm{~g}, 93 \mathrm{mmol})(\mathrm{LAH})$ was added dropwise with stirring at $00^{\circ} \mathrm{C}$ under nitrogen. The reaction mixtures were kept for $2 \mathrm{~h}$ at $0^{\circ} \mathrm{C}$ and for $5 \mathrm{~h}$ at room temperature. The mixtures were poured into $10 \mathrm{~mL}$ of water and $50 \mathrm{~mL}$ of ethanol and extracted with $500 \mathrm{~mL}$ of diethyl ether. The extractions were washed with water and dried with $\mathrm{MgSO}_{4}$. A rotary evaporator was used to remove diethyl ether. The pure product $\mathbf{5}$ after recrystallization with diethyl ether and hexane, was obtained as a colorless solid in $53 \%(6.67 \mathrm{~g})$ yield.

${ }^{3} \mathrm{H}$ NMR $\left(300 \mathrm{MHz}, \mathrm{CDCl}_{3}\right) \delta 4.80\left(\mathrm{~s}, 2 \mathrm{H},-\mathrm{CH}_{2} \mathrm{OH}\right) 4.74$ $\left(\mathrm{s}, 2 \mathrm{H},-\mathrm{CH}_{2} \mathrm{OH}\right) 2.94\left(\mathrm{t}, 2 \mathrm{H},-\mathrm{CH}_{2} \mathrm{CH}_{2} \mathrm{R}\right) 2.17(\mathrm{~s}, 1 \mathrm{H},-\mathrm{OH})$ $1.75\left(\mathrm{~m}, 2 \mathrm{H},-\mathrm{CH}_{2}-\mathrm{CH}_{2}-\mathrm{R}\right) 1.26\left(\mathrm{~s}, 12 \mathrm{H},-\mathrm{CH}_{2}-\left(\mathrm{CH}_{2}\right)_{6}-\mathrm{R}\right)$ $0.87\left(\mathrm{t}, 3 \mathrm{H},-\mathrm{CH}_{3}\right) ;{ }^{13} \mathrm{C} \mathrm{NMR}\left(75 \mathrm{MHz}, \mathrm{CDCl}_{3}\right) \delta 170.98$, $150.99,133.99,55.77,55.50,33.22,31.82,30.08,29.42$, $29.28,29.24,29.11,22.62,14.06 . ; \mathrm{IR}(\mathrm{KBr}) \mathrm{v}_{\max } 3297(\mathrm{OH})$, $3094,2956,2926,2853,1478,1032 \mathrm{~cm}^{-1}$; Anal. Calcd for 
$\mathrm{C}_{14} \mathrm{H}_{25} \mathrm{NO}_{2} \mathrm{~S} ; \mathrm{C}, 61.95 ; \mathrm{H}, 9.28 ; \mathrm{N}, 5.16 ; \mathrm{O}, 11.79 ; \mathrm{S}$, $11.81 \%$. Found: $\mathrm{C}, 61.94 ; \mathrm{H}, 9.29 ; \mathrm{N}, 5.16 ; \mathrm{O}, 11.29 ; \mathrm{S}$, $11.69 \%$

2-Nonyl-4,5-bis(bromomethyl) thiazole (4). To a solution of compound $5(6.5 \mathrm{~g}, 23.9 \mathrm{mmol})$ in $100 \mathrm{~mL}$ of dried THF, pyridine $(1.57 \mathrm{~mL}, 22.3 \mathrm{mmol})$ was added dropwise with stirring at $0^{\circ} \mathrm{C}$ under nitrogen. The mixtures were kept for $15 \mathrm{~min}$ at $0^{\circ} \mathrm{C}$. Phosphorous tribromide $(4.48 \mathrm{~mL}, 47.8$ mmol) was slowly added to the reaction mixtures at $0^{\circ} \mathrm{C}$. The final mixtures were kept for $1 \mathrm{~h}$ at $0^{\circ} \mathrm{C}$, and for $6 \mathrm{~h}$ at room temperature. The mixtures were neutralized by 100 $\mathrm{mL}$ of saturated $\mathrm{NaHCO}_{3}$ in ice water and extracted $200 \mathrm{~mL}$ of $\mathrm{CH}_{2} \mathrm{Cl}_{2}$. The extractions were washed with water and dried with $\mathrm{MgSO}_{4}$. A rotary evaporator was used to remove $\mathrm{CH}_{2} \mathrm{Cl}_{2}$. The pure product, after residue was purified by column chromatographic purification on silica gel with ethyl acetate and hexane (1:19) as eluent solvent, was obtained as a brightly yellow oil in $98 \%$ yield $(9.33 \mathrm{~g})$.

${ }^{1} \mathrm{H} \mathrm{NMR}\left(300 \mathrm{MHz}, \mathrm{CDCl}_{3}\right) \delta 4.68\left(\mathrm{~s}, 2 \mathrm{H},-\mathrm{CH}_{2} \mathrm{Br}\right) 4.56$ (s, $\left.2 \mathrm{H},-\mathrm{CH}_{2} \mathrm{Br}\right) 2.92\left(\mathrm{t}, 2 \mathrm{H},-\mathrm{CH}_{2} \mathrm{CH}_{2} \mathrm{R}\right) 1.76\left(\mathrm{~m}, 2 \mathrm{H},-\mathrm{CH}_{2}-\right.$ $\left.\mathrm{CH}_{2}-\mathrm{R}\right) 1.26\left(\mathrm{~s}, 12 \mathrm{H},-\mathrm{CH}_{2}-\left(\mathrm{CH}_{2}\right)_{-}-\mathrm{R}\right) 0.88\left(\mathrm{t}, 3 \mathrm{H},-\mathrm{CH}_{3}\right)$; ${ }^{13} \mathrm{C} \mathrm{NMR}\left(75 \mathrm{MHz}, \mathrm{CDCl}_{3}\right) \delta 171.64,149.47,131.75,33.58$, $32.45,31.72,30.81,29.69,29.27,29.12,28.96,23.93$, $22.55,21.73,14.03$; IR (KBr) $v_{\text {nux }} 2922,2849,1535,1487$, $1462,1432,1097,609 \mathrm{~cm}^{-1}$; Anal. Caled for $\mathrm{C}_{14} \mathrm{H}_{23} \mathrm{Br}_{2} \mathrm{NS}$ : C, 42.33; H, 5.84; Br, 40.23; N, 3.53; S, 8.07\%. Found: C, $42.31 ; \mathrm{H}, 5.86 ; \mathrm{Br}, 40.24 ; \mathrm{N}, 3.62 ; \mathrm{S}, 8.17 \%$.

2-Nonyl-4,6-dihydro-thieno[3,4- $d]$ thiazole $\quad(3)$. To a solution $\mathrm{Na}_{2} \mathrm{~S} \cdot 9 \mathrm{H}_{2} \mathrm{O}(5.6 \mathrm{~g}, 23.4 \mathrm{mmol})$ in $500 \mathrm{~mL}$ of dried ethyl alcohol at $0^{\circ} \mathrm{C}$, a solution of compound $4(9.3 \mathrm{~g}, 23.4$ mmol) in $150 \mathrm{~mL}$ of ethyl alcohol was slowly dropwise with stirring at $0^{\circ} \mathrm{C}$ under nitrogen. The mixtures were stirred under nitrogen for $1 \mathrm{~h}$ at $0{ }^{\circ} \mathrm{C}$, and for $1 \mathrm{~h}$ at room temperature under nitrogen. The ethyl alcohol was removed under reduced pressure. It was extracted several times with hexane. The combined hexane extracts were removed under reduced pressure. After removal of the hexane solvent, the crude product was purified by column chromatography by using ethyl acetate and hexane (1:19) as eluent solvent to afford yellow oil product $3(2.26 \mathrm{~g}, 36 \%)$.

${ }^{1} \mathrm{HNMR}\left(300 \mathrm{MHz}, \mathrm{CDCl}_{3}\right) \delta 4.10\left(\mathrm{~s}, 4 \mathrm{H},-\mathrm{CH}_{2} \mathrm{~S}\right) 2.93(\mathrm{t}$, $\left.2 \mathrm{H},-\mathrm{CH}_{2}-\mathrm{CH}_{2} \mathrm{R}\right) 1.76\left(\mathrm{~m}, 2 \mathrm{H},-\mathrm{CH}_{2}-\mathrm{CH}_{2}-\mathrm{R}\right) 1.26(\mathrm{~s}, 12 \mathrm{H}$, $\left.-\mathrm{CH}_{2}-\left(\mathrm{CH}_{2}\right)_{6}-\mathrm{R}\right) 0.88\left(\mathrm{t}, 3 \mathrm{H},-\mathrm{CH}_{3}\right) ;{ }^{13} \mathrm{C} \mathrm{NMR}(75 \mathrm{MHz}$, $\left.\mathrm{CDCl}_{3}\right) \delta 176.74,157.42,130.05,34.38,32.03,31.75$, $30.31,29.86,29.33,29.18,29.16,28.92,22.57,14.02$; GCMS (rel., intensity) $269(22, \mathrm{M}), 236(4), 226(7), 212(9)$, $197(3), 184(5), 170(31), 157(100), 133(2), 116(5), 96$ (3), $83(2), 71(4)$; IR (KBr) $v_{\text {n1 } 1 x} 2924,2853,1459,1343$, $1152 \mathrm{~cm}^{-1}$.

2-Nonyl-thieno[3,4- $d]$ thiazole (2). To a solution of compound $3(1.13 \mathrm{~g}, 4.2 \mathrm{mmol})$ in $50 \mathrm{~mL}$ of benzene, 2,3dichloro-5,6-dicynide-1,4-benzoquinone (DDQ) $(0.95 \mathrm{~g}, 4.2$ mmol) was slowly added with stirring at $5{ }^{\circ} \mathrm{C}$ under nitrogen. The reaction mixtures were kept for about $18 \mathrm{~h}$ at 5 ${ }^{\circ} \mathrm{C}$. The color of the solution changed from red to dark yellow. After removal of the solvent, the crude product was purified by column chromatography using ethylacetate and hexane $(1: 19)$ as eluent solvent to afford the product $(1.07 \mathrm{~g}$, $96 \%$ ).

'H NMR $\left(300 \mathrm{MHz}, \mathrm{CDCl}_{3}\right) \delta 7.45$ (d, 1H, -CHS) 7.15 (d, $1 \mathrm{H},-\mathrm{CHS}) 2.98\left(\mathrm{t}, 2 \mathrm{H},-\mathrm{CH}_{2}-\mathrm{CH}_{2} \mathrm{R}\right) 1.83\left(\mathrm{~m}, 2 \mathrm{H},-\mathrm{CH}_{2}-\right.$ $\left.\mathrm{CH}_{2}-\mathrm{R}\right) 1.26\left(\mathrm{~s}, 12 \mathrm{H},-\mathrm{CH}_{2}-\left(\mathrm{CH}_{2}\right)_{6}-\mathrm{R}\right) 0.88\left(\mathrm{t}, 3 \mathrm{H},-\mathrm{CH}_{3}\right)$; ${ }^{13} \mathrm{C}$ NMR $\left(75 \mathrm{MHz}, \mathrm{CDCl}_{3}\right) \delta 178.84,159.87,134.06$, $109.67,109.31,35.30,31.81,29.37,29.24,29.22,29.07$, $28.86,22.63,14.08$; GC-MS (rel., intensity) $267(21, \mathrm{M})$, $224(5), 210(20), 197(9), 182(3), 168(41), 155(100), 142$ (3), $131(3), 110(3), 69(6) ; \mathrm{IR}(\mathrm{KBr}) v_{\max } 3112,2953,2925$, $2854,1551,1530,1499,1465,1335,1081,757 \mathrm{~cm}^{-1}$.

Poly(2-nonyl-thieno[3,4- $d$ thiazole) (1). ${ }^{1} \mathrm{H}$ NMR $(300$ $\left.\mathrm{MHz}, \mathrm{CDCl}_{3}\right) \delta 2.98\left(\mathrm{t}, 2 \mathrm{H},-\mathrm{CH}_{2}-\mathrm{CH}_{2} \mathrm{R}\right) 1.83(\mathrm{~m}, 2 \mathrm{H}$, $\left.-\mathrm{CH}_{2}-\mathrm{CH}_{2}-\mathrm{R}\right) 1.26\left(\mathrm{~s}, 12 \mathrm{H},-\mathrm{CH}_{2}-\left(\mathrm{CH}_{2}\right)_{6}-\mathrm{R}\right) 0.88(\mathrm{t}, 3 \mathrm{H}$, $\left.-\mathrm{CH}_{3}\right) ;{ }^{13} \mathrm{C} \mathrm{NMR}\left(75 \mathrm{MHz}, \mathrm{CDCl}_{3}\right) \delta 178.84,165.76$, $135.21,109.45,109.34,35.32,31.71,29.47,29.23,29.12$, $29.05,28.86,22.43,14.10 ; \mathbb{R}(\mathrm{KBr}) v_{\max } 2953,2922,2851$, $1551,1465,1317,1234,1094,907,848,719 \mathrm{~cm}^{-1}$; Anal. Calcd for $\mathrm{C}_{14} \mathrm{H}_{19} \mathrm{NS}_{2}: \mathrm{C}, 63.35 ; \mathrm{H}, 7.21 ; \mathrm{N}, 5.28 ; \mathrm{S}, 24.16 \%$. Found: C, 62.98; H, 7.37; N, 5.12; S, 24.35\%.

Acknowledgements. This research was supported by the MIC (Ministry of Information and Communication), Korea, under the ITRC (Information Technology Research Center) support program supervised by the IITA (Institute of Information Technology Assessment) (ITA-2006-C1090-06030018 ) and Kwangwoon University (2006). This research was conducted in 2006 during the sabbatical research year of Kwangwoon University.

\section{References}

I. Kim, I. T.; Lee, S. W.; Kwak, T. H.; Lee, J. Y.; Park, H. S.; Kim, S. Y.; Lee, C. M.; Jung, H. E.; Kang, J.-G.; Kim, T.-J.; Kang, H.-J.; Park, C. M.; Elsenbaumer, R. L. Macromol. Rapid Comm. 2002, $2,3,551$.

2. Meng, H.; Wudl, F. Macromolecules 2001, $34,1810$.

3. Pomeraniz, M.; Chaloner-Gill, B.; Harding, L. O.; Tseng, J. J.; Pomertantz. W. J. J. Chem. Soc., Chem. Conmint. 1992, 1672.

4. (a) Lee, K.; Sotzing, G. A. Macromolecules 2001, 34, 5745. (b) Pomertantz. M.; Gu, X.; Zhang. S. X. Macromolecules 2001, 34 . 1817.

5. Bredas, J. L.; Heeger, A. J.; Wudl, F. J. Chem. Phys, 1896, 85, 4673.

6. Kim. J. T.; Elsenbaumer, R. L. Mocromolectles 2000, 34, 6407.

7. Kim, I. T.; Lee, J. Y.; Lee, S. W. Chem. Lett. 2004, 46.

8. (a) Ralston, A. W; Hoerr, C. W.; Pool, W. O. J. Org. Chem. 1943 , 8, 473. (b) Walter, W.; Bode, K. D. Angew. Chem. Intern. Ed. (Engl, 1966, 5(5), 447. (c) Holton, G. W.; Parker, G.; Alexander, R. J. Chem. Soc. 1949, 2049 . 